\title{
NOVÉ VČASNOSTREDOVEKÉ NÁLEZY Z TURCA $^{1}$
}

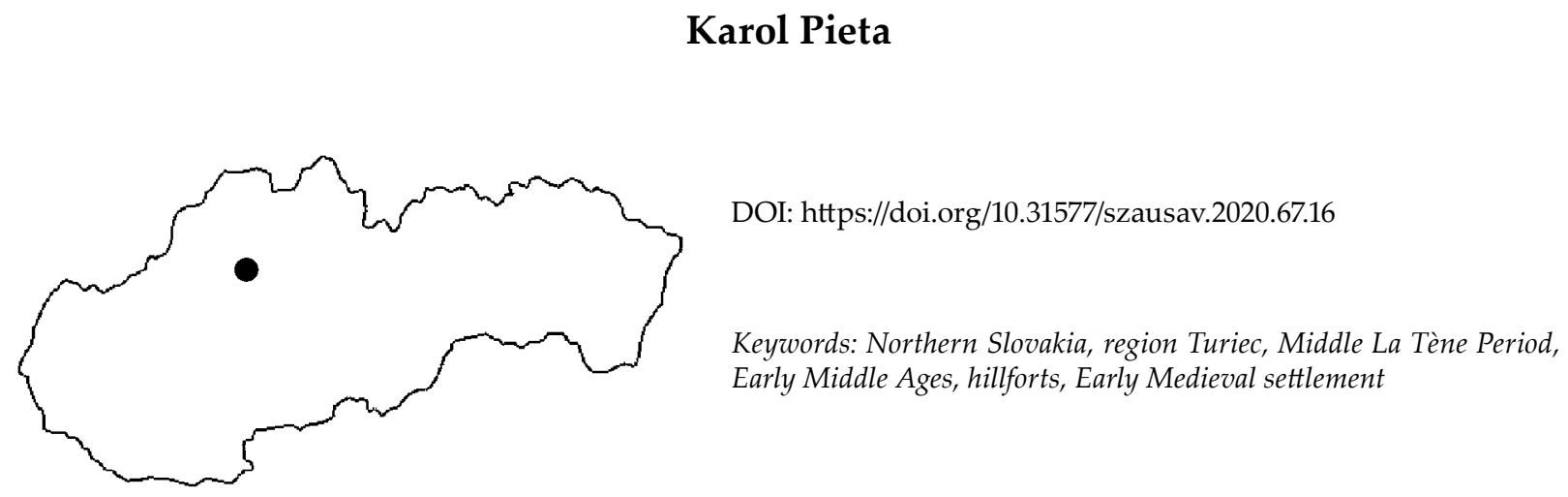

New early medieval finds from Turiec

The surveys of the eastern foothills of the Malá Fatra Mountains (northern Slovakia) have brought new information about the settlement of the Turiec region. In the hillfort with double rampart lines on a rocky hill not far from Ondrašová, district Turčianske Teplice, isolated finds from the Middle La Tène period and intensive early medieval settlement were found. This fortification and nearby newly discovered sites in Abramová-Polerieka and Zniev significantly increased the number of hill top settlements from the $9^{\text {th }}-10^{\text {th }}$ century in the region, where until now mainly small agricultural settlements and burial mounds were investigated.

\section{ÚVOD}

Systematický terénny prieskum regiónu Turca sa v ostatných rokoch sústredil na predhoria Velkej a Malej Fatry, kde priniesol množstvo nových poznatkov o pravekom a včasnohistorickom osídlení (Horňák 2015; Pieta 2014). Bola tu rozpoznaná a skúmaná pozoruhodná koncentrácia opevnení a výšinných sídlisk z neskorej doby bronzovej a z doby železnej, s najväčším rozmachom v dobe laténskej, v staršej fáze púchovskej kultúry. V rovnakej dobe, ako sa zdá, vrcholí intenzita staršieho osídlenia celého regiónu Turca. Menej informácií máme o počiatkoch stredoveku. Túto medzeru do určitej miery vyplńajú výsledky terénnych aktivít vo východných predhoriach Malej Fatry.

\section{HRADISKO V ONDRAŠOVEJ}

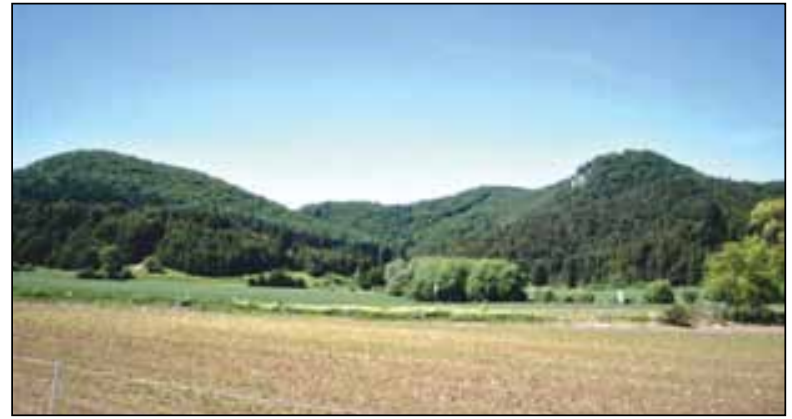

Obr. 1. Ondrašová, Ondrašovské skaly. Celkový pohlad od juhozápadu. Foto K. Pieta.
Systematický terénny prieskum sa sústredil na horskú čast' katastra obce Ondrašová, okres Turčianske Teplice v priestore masívu Ondrašovských skál, ktoré sú súčastou východných výbežkov Malej Fatry (obr. 1). Lokalita sa nachádza na východnom konci skalnatého vápencového hrebeňa, prebiehajúceho $\mathrm{v}$ smere $\mathrm{Z}-\mathrm{V}$ a pokrýva ju vysoký bukovo-smrekový les. $\mathrm{Na}$ západnej strane hrebeň pretína križovatka starých lesných ciest, vedených miestami v hlbokých úvozoch. Terén bol narušený ilegálnymi hladačmi a lokalita zrejme nebola doteraz evidovaná.

1 Príspevok vznikol s podporou grantového projektu VEGA 2/0001/18 „Slovensko a stredné Podunajsko: vývoj od včasnej doby dejinnej po začiatok stredoveku“, projektu APVV-19-0563 „Mocenské centrá a ich zázemie v 8.-11. storoči“ a ako dopadový ukazovatel’ udržatelnosti projektu ITMS: 26220120059. 
Hrebeň kopca $\mathrm{v}$ mieste rozšírenia $\mathrm{v}$ severojužnom smere pretína val, ktorý na viacerých miestach prepája skalné ihly a bralá (obr. 2). V južnej časti sa zatáča $\mathrm{v}$ pravom uhle a jeho viditelná čast’ sa končí v strmom svahu nad bralami, ktoré poskytujú tomuto miestu prirodzenú ochranu. Priečna severojužná čast' valu je na dvoch miestach prerušená. Severnejšie z prerušení, kde je severné pokračovanie násypu mierne smerovo posunuté dovnútra, pravdepodobne predstavuje pôvodný vchod do opevnenia po ceste, nastupujúcej do brány šikmo hore svahom $z$ pravej strany. Na dvoch miestach zvnútra tohto úseku valu sú $\mathrm{v}$ teréne viditel'né dve vel'ké obdížnikové priehlbne, azda materiálové jamy. Vnútornú plochu tejto časti hradiska v smere $\mathrm{Z}$ - V rozdeluje línia skalného hrebeňa.

Ďalší valový násyp ohraničuje najvyššiu čast’ vrchu s kótou $811,8 \mathrm{~m}$ (obr. 2). Podla terénneho pozorovania bol navŕšený prevažne z kameňov. Fortifikácia má tvar podkovy a najvyššia je na lahšie prístupnej západnej strane. Tento nevel'ký priestor s rozmermi približne $25 \times 25 \mathrm{~m}$ z východu a juhu chránia bralá. Vstup dovnútra opevnenia možno predpokladat medzi koncom západného valu a južnou skalnou stenou (obr. 3). Na vrchu sa vykonal povrchový zber s použitím detektorov kovov a so zameraním všetkých dôležitejších predmetov. Stopy osídlenia sa zistili už na návršiach a svahoch $\mathrm{v}$ širšom zázemí zemného opevnenia. $Z$ významnejších nálezov možno spomenút laténsku železnú sponu spojenej konštrukcie, ktorá sa našla pod skalami pri južnom úpätí vrchu. Svahy pod hradiskom boli obývané či využívané aj vo včasnom stredoveku. Okrem viacerých ojedinelých nálezov to dokladajú dva kosáky, uložené tesne pod povrchom vedla seba blízko prístupovej cesty k hradisku (obr. 4; 6).

\section{Spona}

Spona s desatnásobným vinutím a vonkajšou tetivou má koniec nôžky ku koncu nízkeho lučíka pripevnený nitom i ozdobnou plastickou svorkou (obr. 5: 6). Patrí do skupiny dlhých
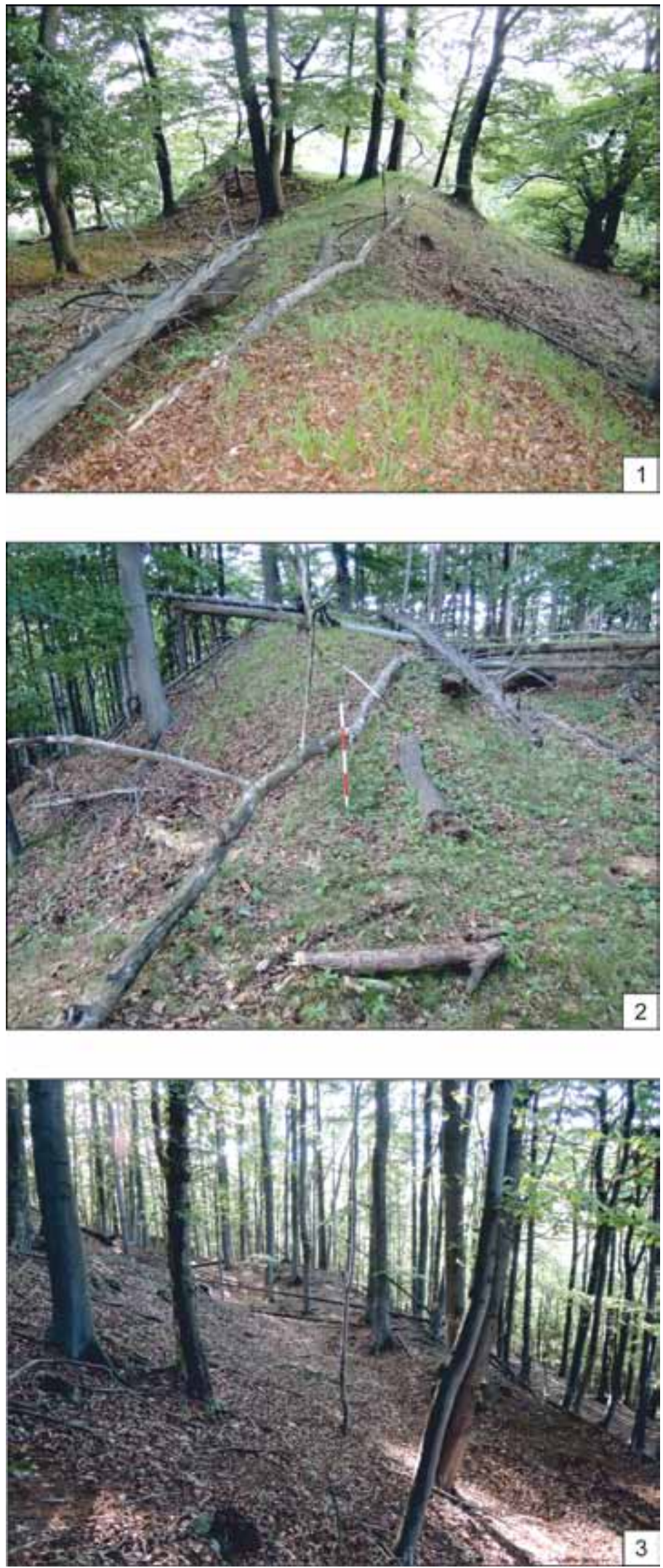

Obr. 2. Ondrašová, Ondrašovské skaly. 1 - pohlad na západnú čast’ vonkajšieho valu od severu; 2 - vnútorný val; 3 - priebeh severného valu, pohlad od juhovýchodu. Foto K. Pieta. 


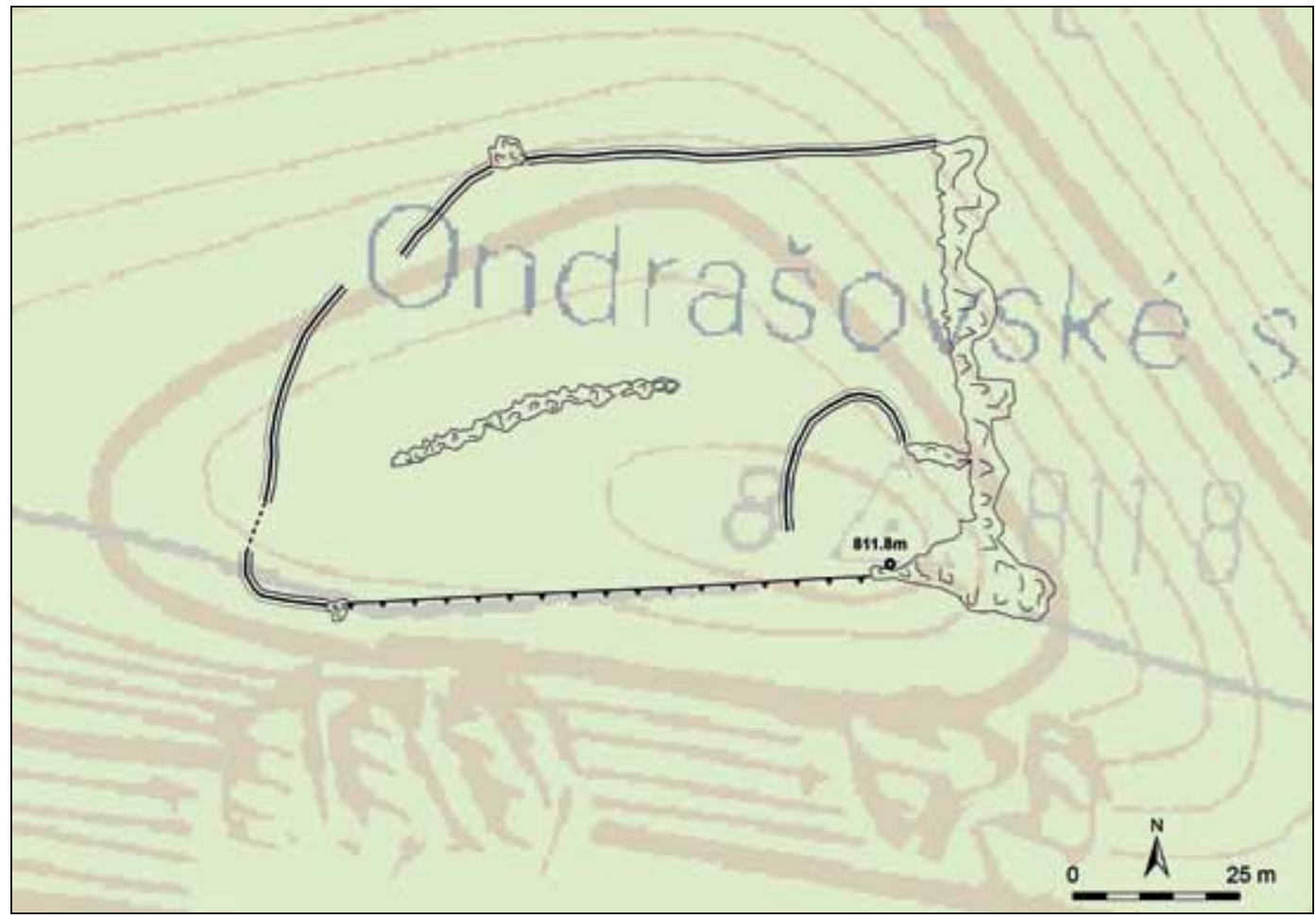

Obr. 3. Ondrašová, Ondrašovské skaly. Plán hradiska. Autori M. Bartík, K. Pieta.

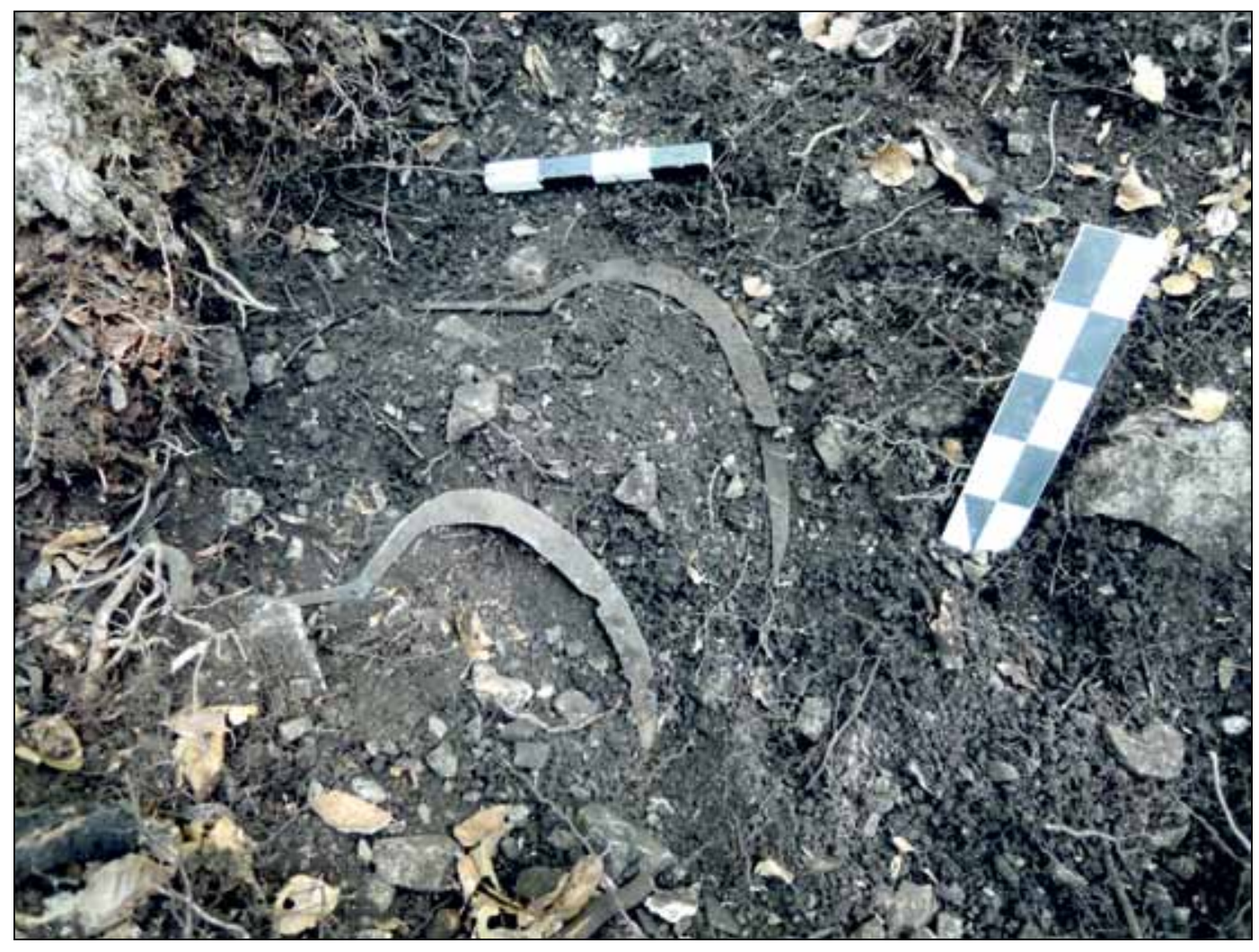

Obr. 4. Ondrašová, Ondrašovské skaly. Nález kosákov v predpolí hradiska. Foto K. Pieta. 

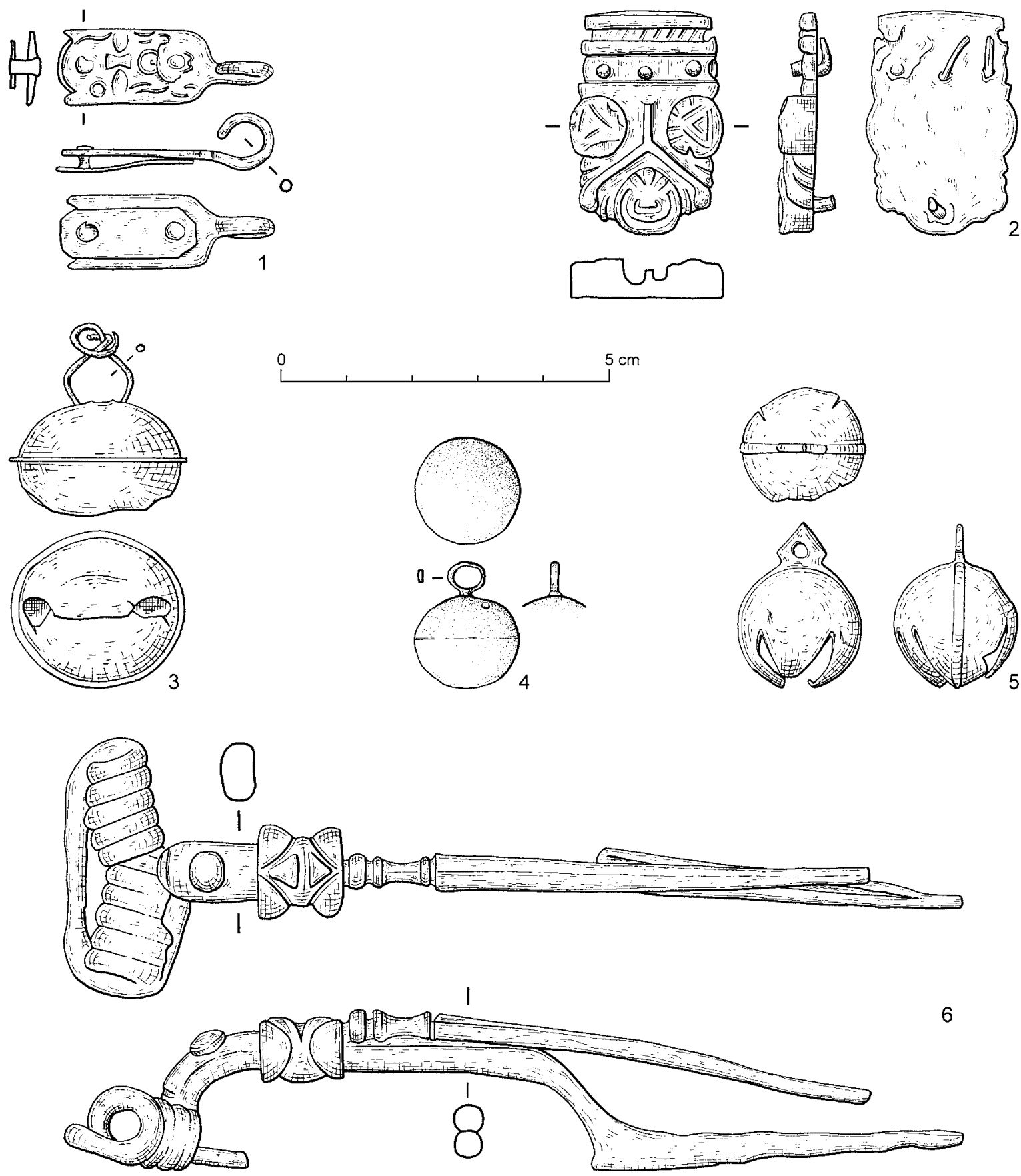

Obr. 5. Ondrašová, Ondrašovské skaly. 1-5 - nálezy z plochy hradiska; 6 - nález pri úpätí vrchu. 1, 3, 4-bronz; 2, 5, 6 - železo.

železných spôn s výrazne členenou pätkou (skupina EF-K, zoskupenie 11: Bujna 2003, 81) zo záverečnej fázy stupňa C1. Zvláštnostou konštrukcie je pripevnenie pätky k lučíku pomocou nitu, čo je zriedkavý technický postup. Nitovanie bolo použité pri masívnych bronzových sponách typu Slovenské Pravno, kde však dvojica nitov pripája špirálu s ihlou k lučíku (Pieta 1982, tab. V: 2, 4). Časové postavenie týchto originálnych lokálnych spínadiel nie je ešte spolahlivo stanovené, avšak podla ich stavby, evidentne inšpirovanej okruhom astragalových spôn juhovýchodného pôvodu, patria niekde na záver stredolaténskeho stupňa C. Sú teda o niečo mladšie ako nález z Ondrašovej. Spona, objavená na úpätí vrchu 


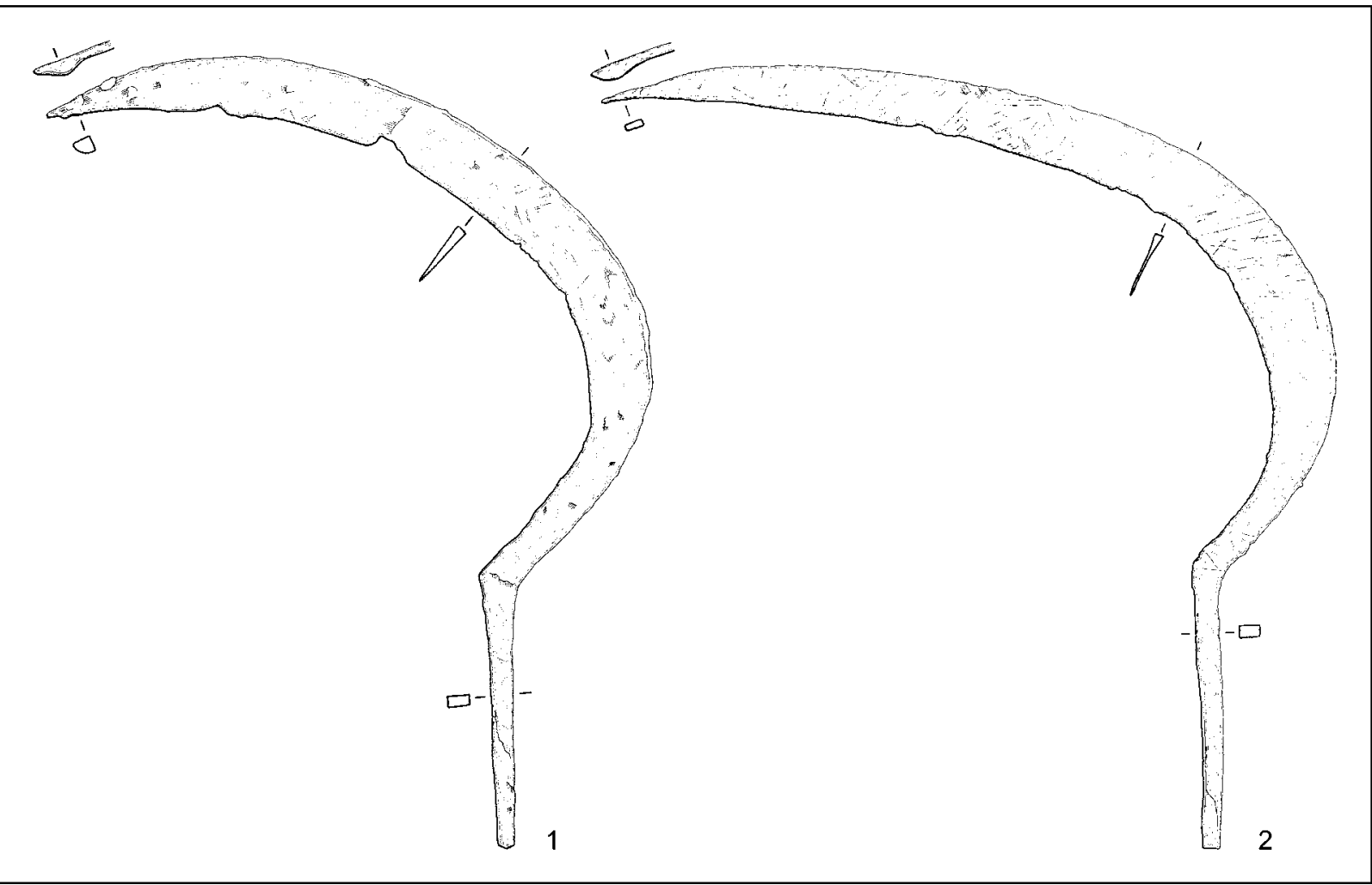

Obr. 6. Ondrašová, Ondrašovské skaly. Kosáky nájdené na západnom predpolí hradiska. Železo.

spolu s dvomi zlomkami grafitovej keramiky z vnútornej plochy hradiska potvrdzuje využitie tohto miesta už v stredolaténskom období.

\section{Kosáky (obr. 6)}

S pomerne širokou oblúkovou čepelou s naplocho vykovaným hrotom a dlhým tŕňom na osadenie rukoväte podla zúbkovaného ostria patria kosáky medzi žatevné náradie. Našli sa ako malý depot pod vrcholom kopca nedaleko prístupovej cesty k hradisku. Patria ku klasickým formám včasnostredovekého žatevného/zberového náradia (Beranová 1991; Borzová 2016, 59; Henning 1987, 89). Podla pozostatkov stebiel rastlín, zachovalých v povrchovej korózii na jednej z čepelí boli oba kosáky uschované či zanechané v kope trávy, slamy. Zlomky i celé kusy tohto masovo rozšíreného náradia každodenného použitia sú častým nálezom na sídliskách, v hroboch a tiež ako súčast’ hromadných nálezov. Vyskytujú sa aj depoty, pozostávajúce výlučne z kosákov. Z nepublikovaných súborov popri vel'kom depote z Pružiny spomeňme dvojicu tohto náradia, ktorá sa našla ako osamotený nález v doline Hradištnica pri Dolných Vesteniciach na Ponitrí. Na konci tejto doliny, pod západným valom hradiska Hradová (Dolné Vestenice II) bol medzi štyrmi hromadnými nálezmi, objavenými po obvode hradiska, aj depot siedmich kosákov toho istého tvaru (Pieta 2019). Doklady osídlenia sa koncentrovali na hradisku. Keramické zlomky a kovové predmety tu boli rozptýlené na celej opevnenej ploche, s koncentráciou vo vnútornom vale na najvyššom mieste hradiska.

\section{Kovania}

Ukončenia remeňa zo železa s tromi upevňovacími nitmi v rade pod okrajom sú zdobené tromi plastickými výčnelkami, ktoré rozdeluje lišta $\mathrm{v}$ tvare písmena $\mathrm{Y}$ (obr. 5: 2). Tento motív spolu s variantom $\mathrm{v}$ tvare písmena $X$ vychádza $\mathrm{z}$ pôvodného zoomorfného ornamentu neskorokarolínskych bronzových predlôh, ktorý sa, azda podla vzorov z oblasti dnešného Slovinska, v zjednodušenom železnom prevedení rozšíril 


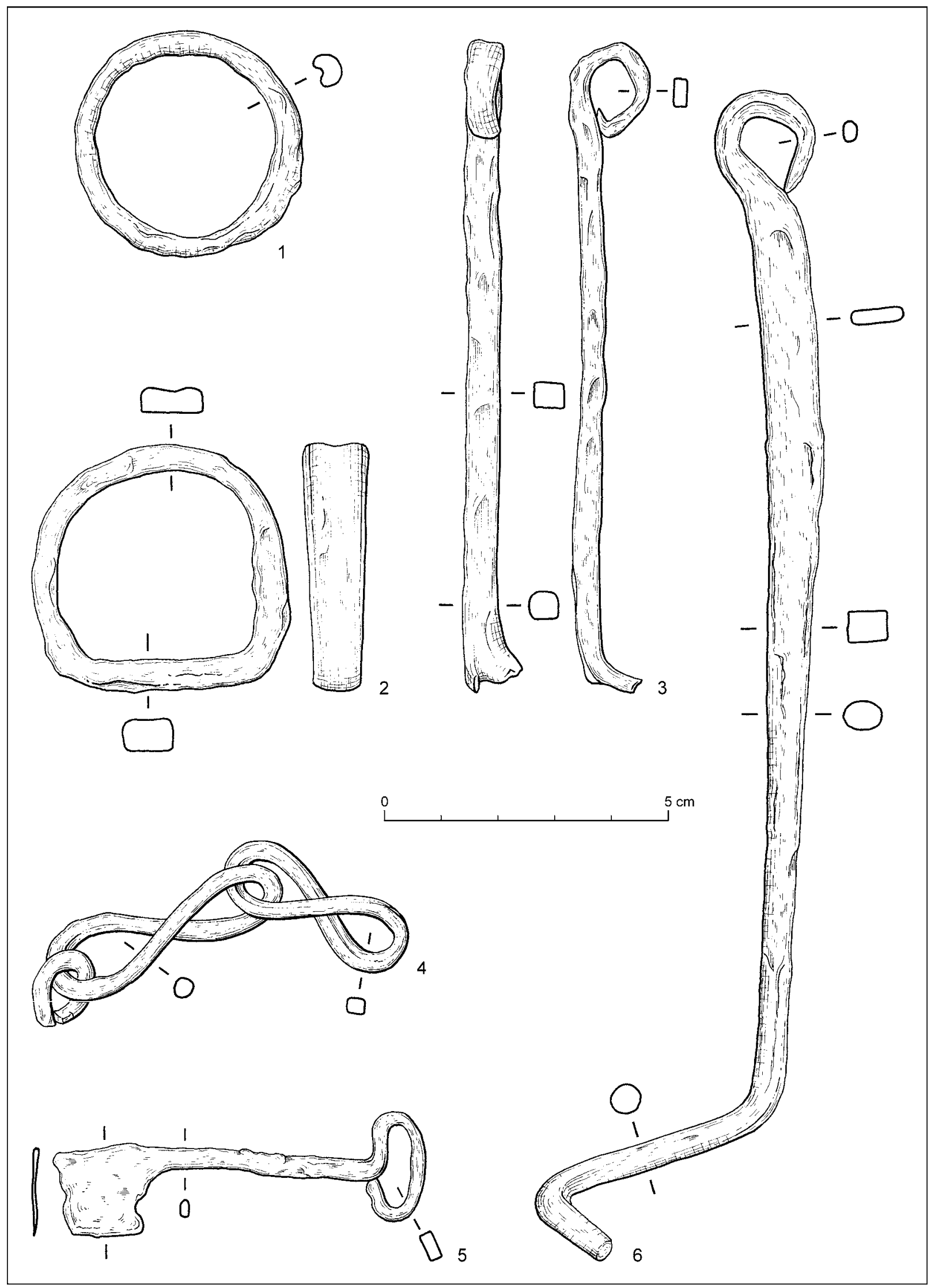

Obr. 7. Ondrašová, Ondrašovské skaly. Nálezy z plochy hradiska. Železo. 
na Moravu a najmä na západné Slovensko, s uplatnením na kovaniach opaskov a na platničkách ostrôh. Najväčší počet týchto aplikovaných prvkov sa našiel na hradisku I v Bojnej, ktoré tažiskovo patrí na koniec 9. storočia (Robak 2013, 179-181, mapa 2). Jednotlivé kusy zdobené touto ornamentikou sa objavujú aj v Turci (Jasenovo, Vyšehrad: Jakubčinová 2018, tab. XLVII: 2) a na Orave (Vyšný Kubín: Čaplovič 1987, obr. 95: 1). Kovanie je dôležité pre časové určenie včasnostredovekého súboru nálezov z hradiska v Ondrašovej.

\section{Hrkálka}

Hrkálka zo železného plechu, nájdená na hradisku (obr. 5: 5), má analógie na hradiskách z 9. storočia, včítane Bojnej. Tieto zvuk vydávajúce ozdoby boli v 8.-9. storočí súčastou konských postrojov, ale aj detských, ženských a ojedinele aj mužských odevov (Csuthy 2019; Pomberger/Stadler 2019). Druhá hrkálka z tenkého bronzového či mosadzného plechu (obr. 5: 3) je pravdepodobne mladšia.

\section{Kl'úče}

Objavené klúče na ploche hradiska patria viacerým systémom uzatvárania dvier, truhlíc a skriniek. V našom prostredí boli používané už v dobe laténskej a rímskej (Czarnecka 2013; Jacobi 1974, 153-166). V takmer nezmenenej podobe sa s nimi stretávame aj vo včasnom stredoveku. Preto klúče z Ondrašovej zarad’ujeme do včasného stredoveku len rámcovo, podla prevažujúceho sprievodného materiálu. Jednoduchý hákový klúč s jedným zubom (obr. 7: 6) má početné paralely na vel'komoravských lokalitách, kde sa objavuje vo viacerých variantoch (Klíma 1980, 42-47). Väčší počet klúčov tohto typu sa našiel na hradisku Bojná I-Valy v sídliskovej vrstve, ako aj v hromadných nálezoch (napr. v dosial' nepublikovanom depote 27/2017). Otočný klúč (obr. 7: 5) sa svojím malým rozmerom a jednoduchým spracovaním odlišuje od kusov tohto typu s okom a plochým zubom, bežných vo včasnostredovekých nálezových súboroch (napr. Vysoké Pole, Kláštov, depot D2: Geisler/Kohoutek 2014, obr. 21: D2/14; Prosiek, Pieta 2016, obr. 2: 13; Pružina, Dolná Maríková, depoty, nepublikované). Technológia plného tela klúča sa ojedinele objavuje aj v tejto dobe, či o niečo skôr (Klíma 1980, 55; Pieta 2007, obr. 7: 7). Klúčik z Ondrašovej zrejme patril k zámke malej skrinky alebo truhličky. Môže však íst' aj o mladší výrobok. Zasúvací klúč (obr. 7: 3) patril k technicky náročnejšiemu systému zámky s odnímatelnou perovou vložkou. Pružinové mechanizmy vychádzajú z antických vzorov a uplatňovali sa najmä pri visiacich zámkoch (Schuster 2010).

\section{Kovanie vedierok}

Z kovaní vedierok sa našli zlomky obručí a najmä charakteristické ataše, ktoré sú v súbore nálezov z hradiska zastúpené viacerými typmi (obr. 8: 1, 2, 4, 7; Hanuliak/Kuzma 2015, 88, 89, s lit.; Klanica 2006, 71-73). Nálezy rozšírili počet i sortiment kovaní drevených nádob z horských oblastí Slovenska (Šalkovský 2011, 62, 63).

Súčastou nálezového inventára sú aj chronologicky neurčitelné predmety dennej potreby, ako šidlá, rezbárske dlátko a závlačka ukončená krúžkom (obr. 9: 1, 2, 5, 7, 9). Háčkovka s tordovaným telom (obr. 9: 6) patrí skôr k laténskej fáze osídlenia.

Nože (obr. 10: 1, 2, 4)

Bežnou súčastou sídliskového inventára boli nože. Prevažná väčšina týchto univerzálnych nástrojov z 9.-10. storočia má rovný chrbát končiaci hrotom a plochý kónický tŕň, ktorý je obvykle odsadený na spodnej strane čepele, ale niekedy aj obojstranne (Bartošková 1986, 86). Tvarom sa od nožíkov z doby rímskej len tažko rozlišujú.

Niektoré z nájdených predmetov signalizujú aj príležitostné využívanie tejto prírodou dobre chránenej polohy aj v nasledujúcich storočiach (obr. 5: 1; 7: 5). Vel'ký a masívny hrot s krídelkami a zvláštnym upevnením pomocou koncového tŕňa (obr. 10:3) pripomína súčasti antických vojenských nástrah v predpoliach pevností, známych aj z popisu G. J. Caesara. Nepochybne ide o stredoveký predmet. 


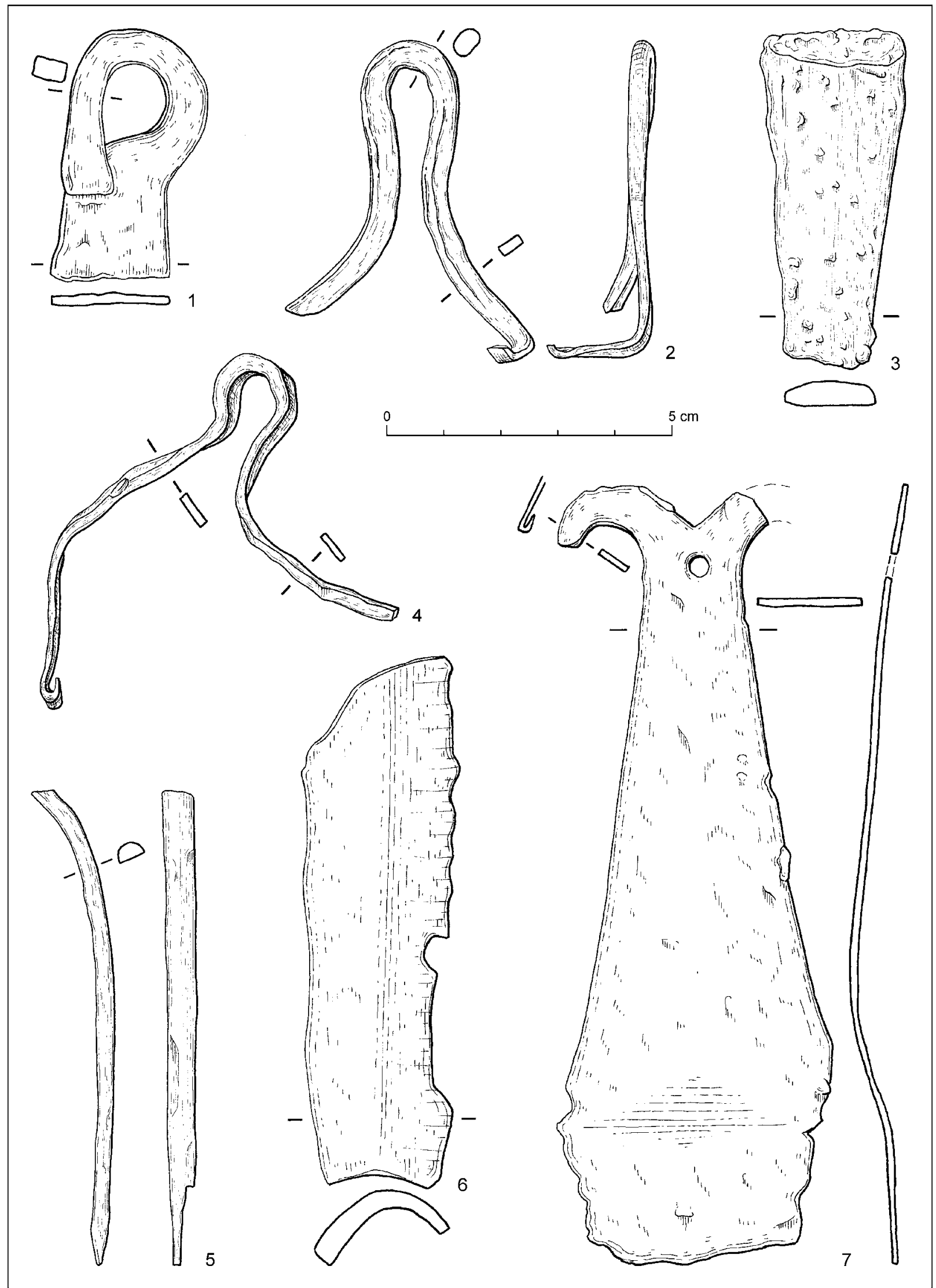

Obr. 8. Ondrašová, Ondrašovské skaly. Časti vedierok a polotovary z plochy hradiska. Železo. 


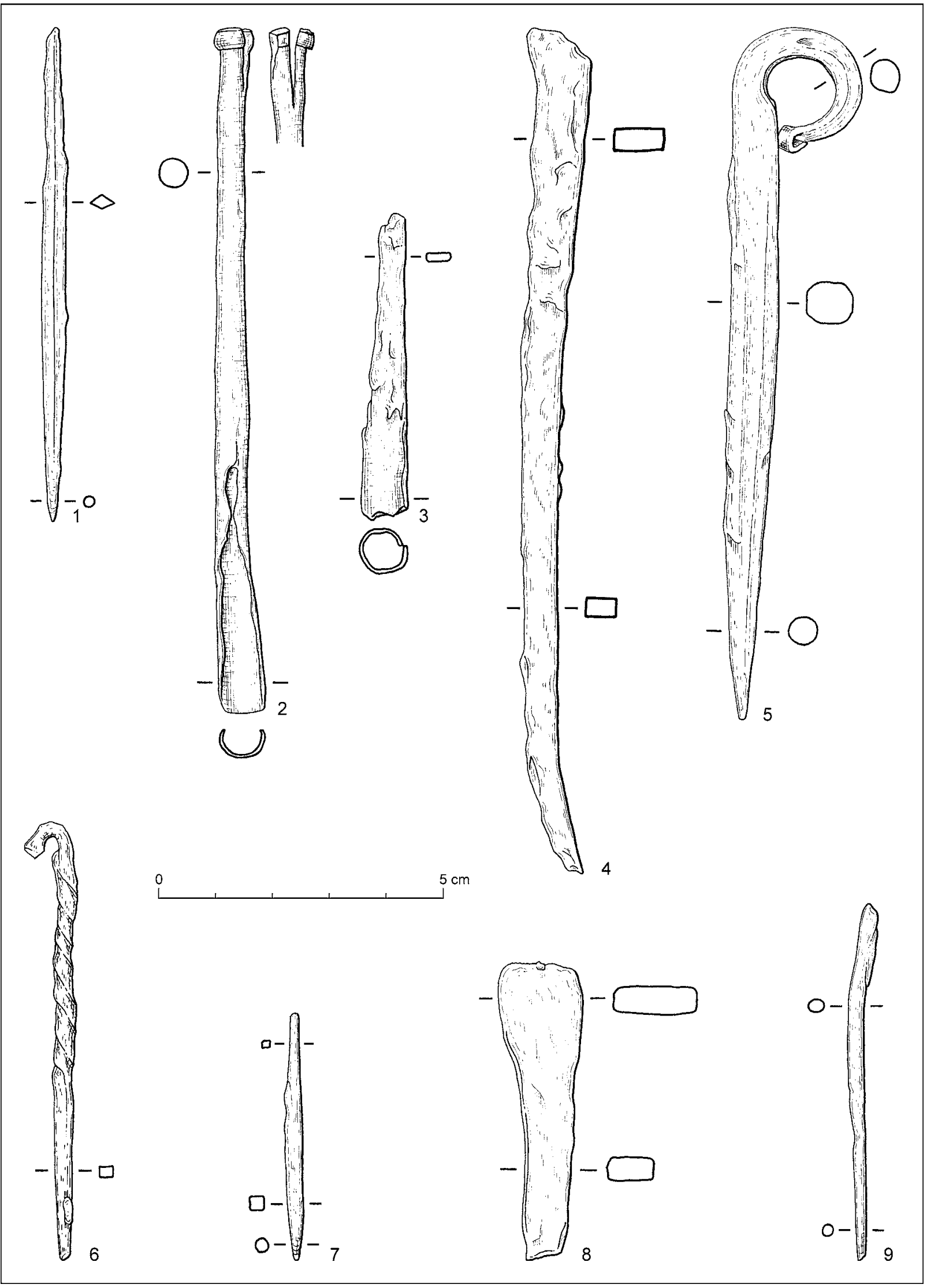

Obr. 9. Ondrašová, Ondrašovské skaly. Nálezy z hradiska. Železo. 


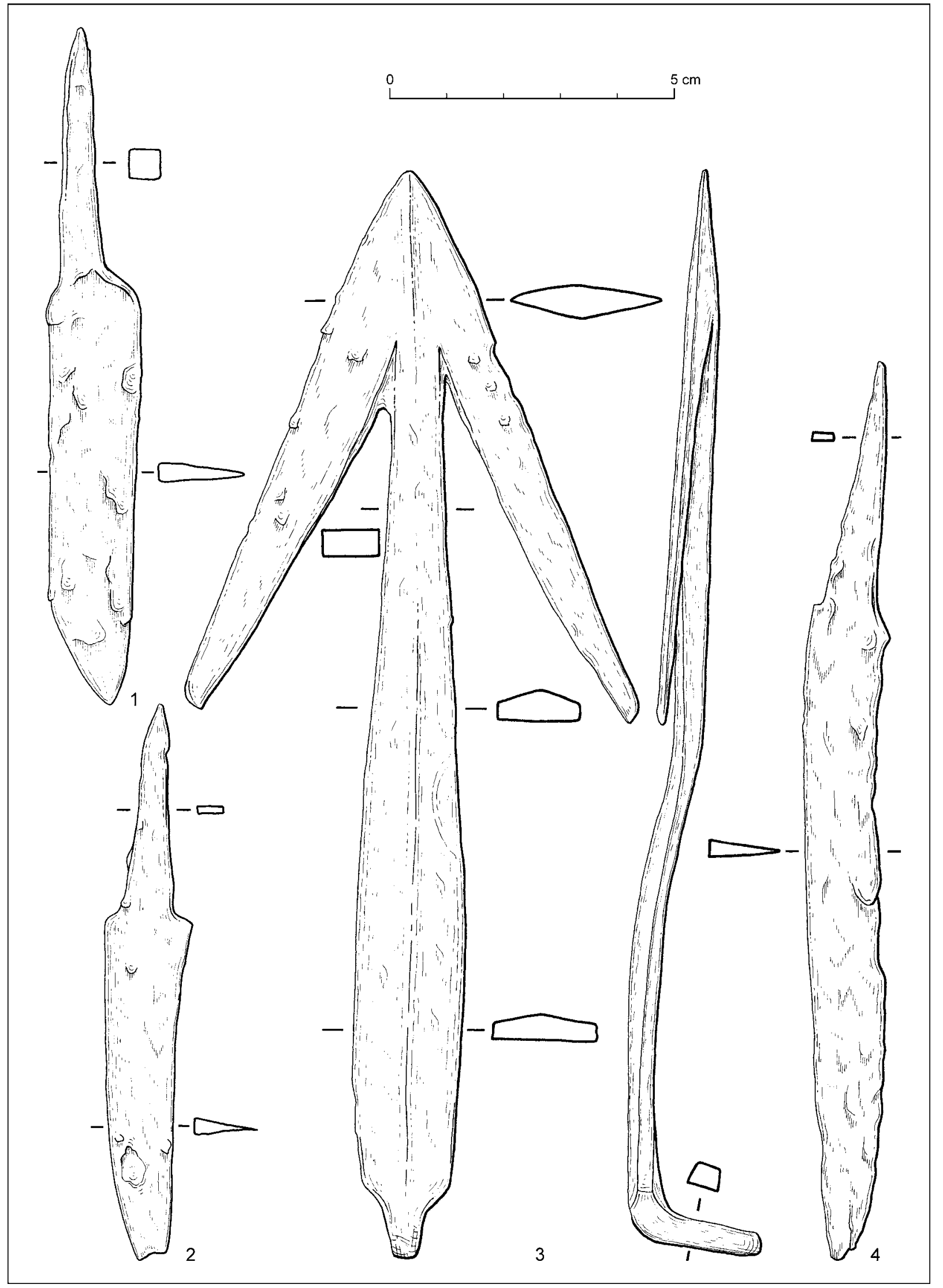

Obr. 10. Ondrašová, Ondrašovské skaly. Hrot a nože z hradiska. Železo. 


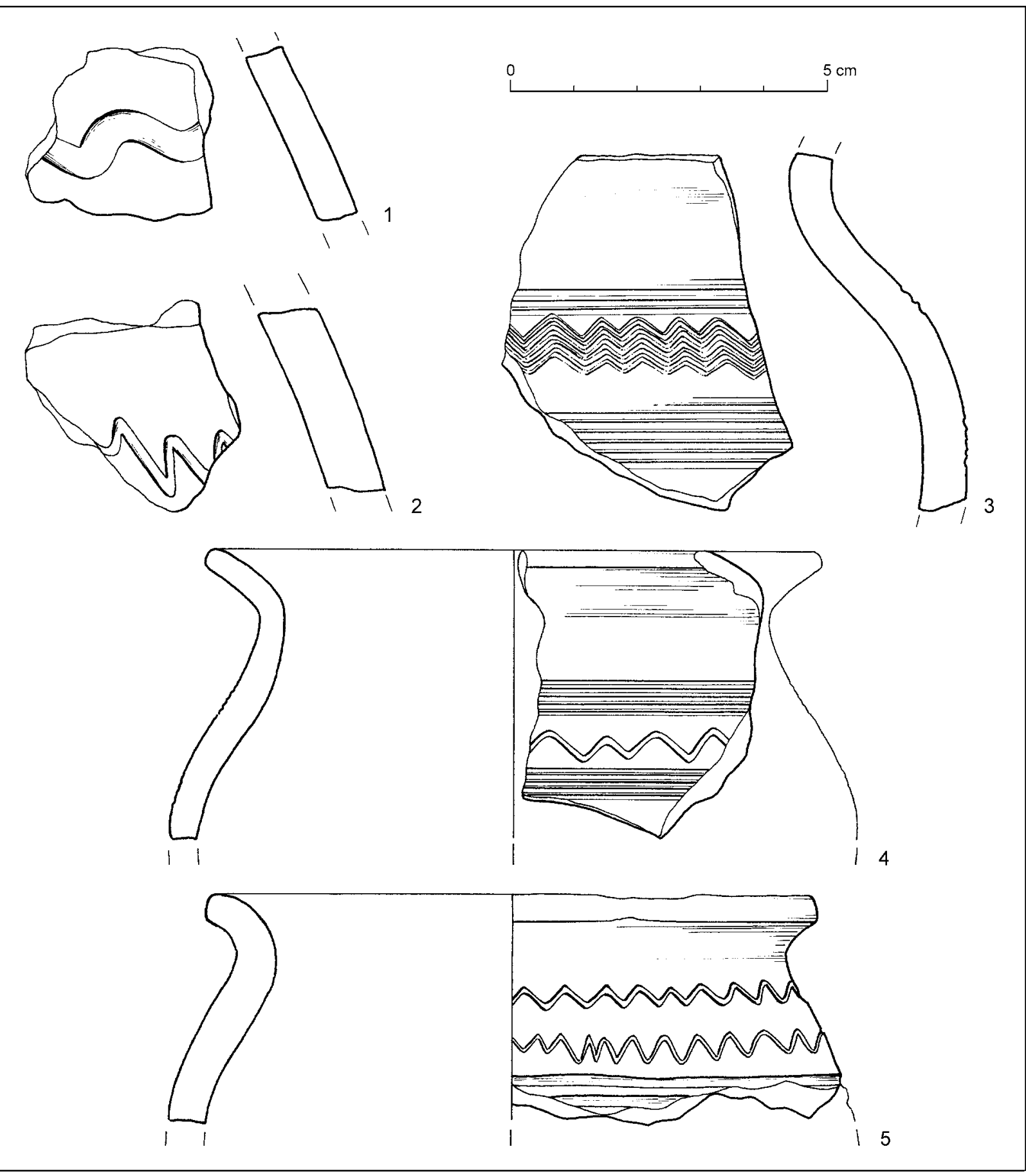

Obr. 11. Ondrašová, Ondrašovské skaly. Keramika z hradiska.

Mohol by to byt' hrot strely do šípometu, ale pravdepodobnejšie to bola súčast’ nástražného obranného alebo loveckého zariadenia. Do stredoveku či včasného novoveku patrí asi aj zlomok zdobeného bronzového predmetu, azda súčast' zápony (obr. 5: 1).

\section{Keramika}

Keramika je $\mathrm{v}$ nálezovom súbore zastúpená zlomkami obtáčaných nádob, zdobených vlnovkami a obvodovými ryhami (obr. 11), ktoré doplńajú pomerne skromnú kolekciu hrnčiarskej produkcie z tohto regiónu (Horňák/Krištofová/Kvietok 2013, 127, 130; Šalkovský 2011, 51, 53; Vanglová 2010). 


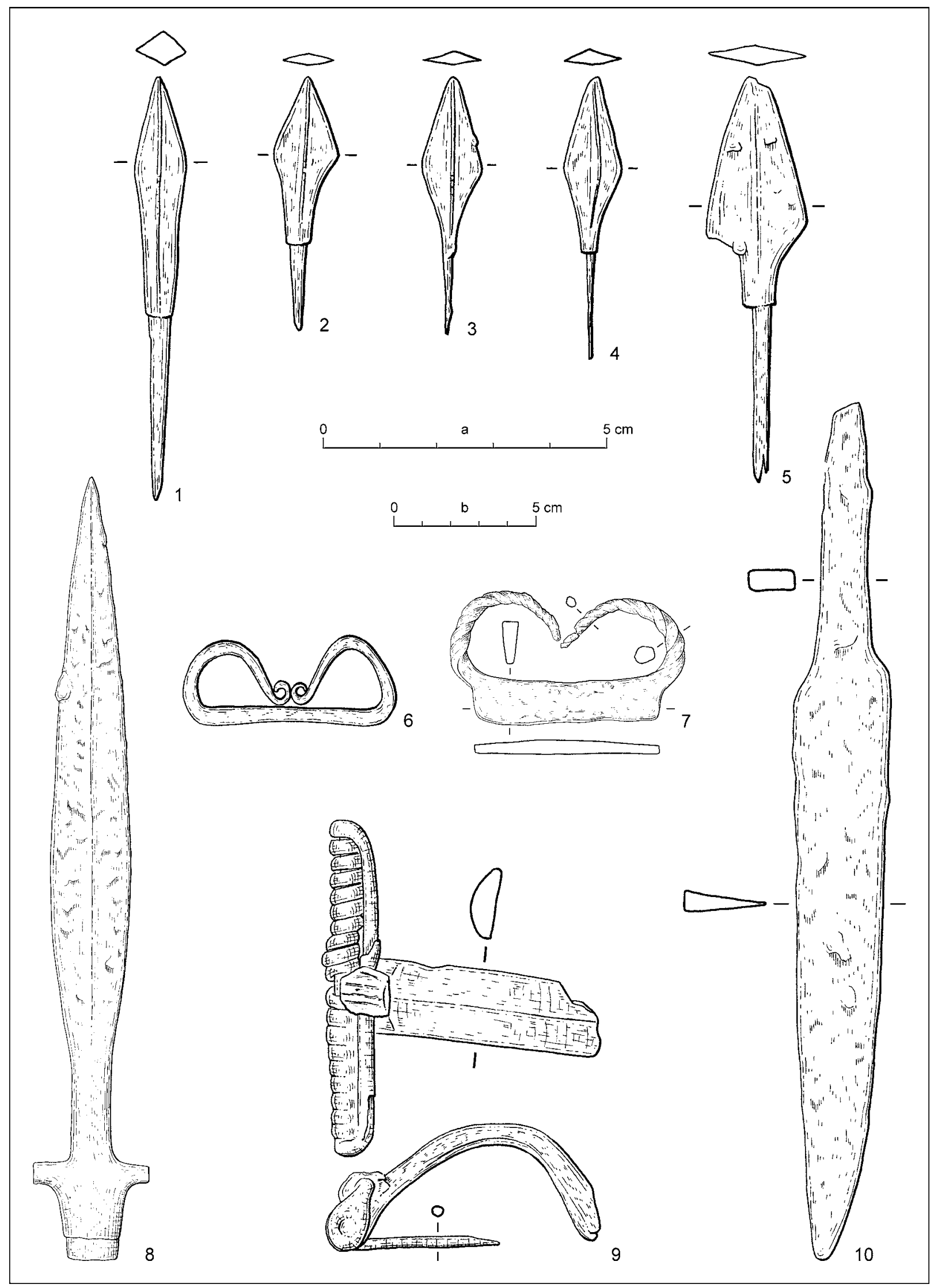

Obr. 12. Abramová-Polerieka. Kóta 567. 1-8, 10 - nálezy z plochy opevnenia; 9 - spona zo svahu kopca. Železo. Mierka: $\mathrm{a}-1-5,9,10 ; \mathrm{b}-6-8$. 
Opevnenie na Ondrašovských skalách pozostáva z dvoch línií valov, ktoré využívali dobré obranné vlastnosti tažko dostupného skalnatého terénu a prepájali jednotlivé bralá na vrchole kopca. Bez detailného výskumu nie je možné rozhodnút, či ide o dvojitú fortifikáciu alebo o valy, budované v rôznych obdobiach. K odpovedi na túto otázku neprispelo ani mapovanie keramiky a kovových predmetov, získaných pri zbere na ploche hradiska. Nálezy sa koncentrovali predovšetkým na vrcholovej plošine uzavretej vnútorným valom, kde sa našli zdobené slovanské črepy, ale i ojedinelé zlomky grafitových, zvislým ryhovaním zdobených laténskych nádob. Časovo určitelné, teda hlavne včasnostredoveké artefakty boli rozptýlené na celej opevnenej ploche. Hypoteticky sa dá uvažovat’ o tom, že jedno z opevnení (väčšie?) bolo vybudované už v strednej dobe laténskej a druhý, vnútorný val bol postavený niekedy v 9. storočí, kedy mohli byt๋ využívané, resp. obrane prispôsobené obe línie opevnení. Získaný materiál je pomerne skromný a svedčí skôr o krátkodobom, zrejme refugiálnom využívaní tejto pomerne odlahlej a tažko prístupnej polohy. Troska a železné polotovary (obr. 8: 3, 6; 9: 8) dokladajú aj lokálnu kováčsku výrobu.

\section{VÝŠINNÉ POLOHY \\ V POLERIEKE A NA ZNIEVE}

Prieskum východného predhoria Malej Fatry priniesol aj d’alšie doklady slovanského osídlenia tejto oblasti.

\section{Abramová-Polerieka, okr. Turčianske Teplice}

Západne od obce nad sútokom potokov Polerieka a Trstenec je zalesnený kopec, ktorý tvorí juhovýchodný výbežok masívu vrchu Žiar $(757 \mathrm{~m})$. Jeho vrchol $(567 \mathrm{~m})$ je v teréne od hrebeňa oddelený viditelnou priekopou. Lokalita sa, žial', stala ciel'om hladačov a jej povrch je silne narušený amatérskymi výkopmi. $Z$ opevneného priestoru pochádza kopija s krídelkami a ploché hroty šípov s tŕňom (obr. 12: $2-5,8$ ). Pri povrchovom zbere sa našla železná troska, zvieracie kosti, fragment žarnova, nožík (obr. 12: 10), dve kresadlá (obr. 12: 6, 7) a črepy z včasného stredoveku. Hrot strely do kuše (obr. 12: 1) svedčí o využívaní tejto polohy aj vo vrcholnom či neskorom stredoveku.

Doklady osídlenia sa nachádzajú aj v okolí opísaného náleziska. Na západne ležiacom svahu je vidiet viaceré terasy, na ktorých sú tiež stopy po hladaní detektorom. Na svahu, severne od opevnenia, sa našli črepy, ktoré patria pravdepodobne púchovskej kultúre a železná spona. Vzhladom na polohu miesta nálezu je možné, že ide o d’alšie z refúgií, charakteristických pre toto krízové obdobie.

Kopija s krídelkami (obr. 12: 8) patrí medzi zbrane so značnou tvarovou variabilitou i dlhším časovým rozpätím ich používania v priebehu 8. a 9.-10. storočia. Kus z Abramovej-Polerieky s dížkou 466 mm patrí podla triedenia M. Husára k jeho typu BA, variant d (Husár 2014, 33-36), kam patrí aj kopija z problematickej kolekcie nálezov, pochádzajúcej údajne z Blatnice (Robak 2017, 131). Hrot s krídelkami z hromadného nálezu z Prosieka, okres Liptovský Mikuláš, patrí podla sprievodných predmetov, najmä ostrôh s palmetovite formovanými platničkami skôr do záverečnej doby obluby tohto typu zbrane (Pieta 2016, 265, 266).

Hroty šípov s plochou čepelou a tŕňom (obr. 12: 2-5, 8) patria k typom A.V.1.Za a A.IV.b.1.Zb (Holeščák 2019, 38-40) so širším datovaním, ktoré aj vzhladom na zberový charakter nálezov neprispieva k spresneniu časového rámca lokality.

Spona s dlhým samostrelovým vinutím, zhotovená zo železa je blízka typu Almgren 148 (obr. 12: 9). Tieto spínadlá patria do inventára konca staršej doby rímskej a $\mathrm{v}$ danej oblasti zároveň do záverečnej fázy púchovskej kultúry (Pieta/Švihurová 2019, obr. 2: 11).

\section{Kláštor pod Znievom-Zniev, okr. Martin}

Prieskumy priniesli poznatky aj o dosial’ málo známej výšinnej lokalite v okolí stredovekého hradu Zniev, postaveného v značnej nadmorskej výške $(985 \mathrm{~m})$. Na hrebeni kopca s ruinami kamenných architektúr a obranných zariadení sa v minulosti vykonal archeologický výskum, ale zo staršieho osídlenia spred doby založenia hradu sa v literatúre spomínajú len ojedinelé „mladohradištné“ črepy (Balaša 1964, 266). 


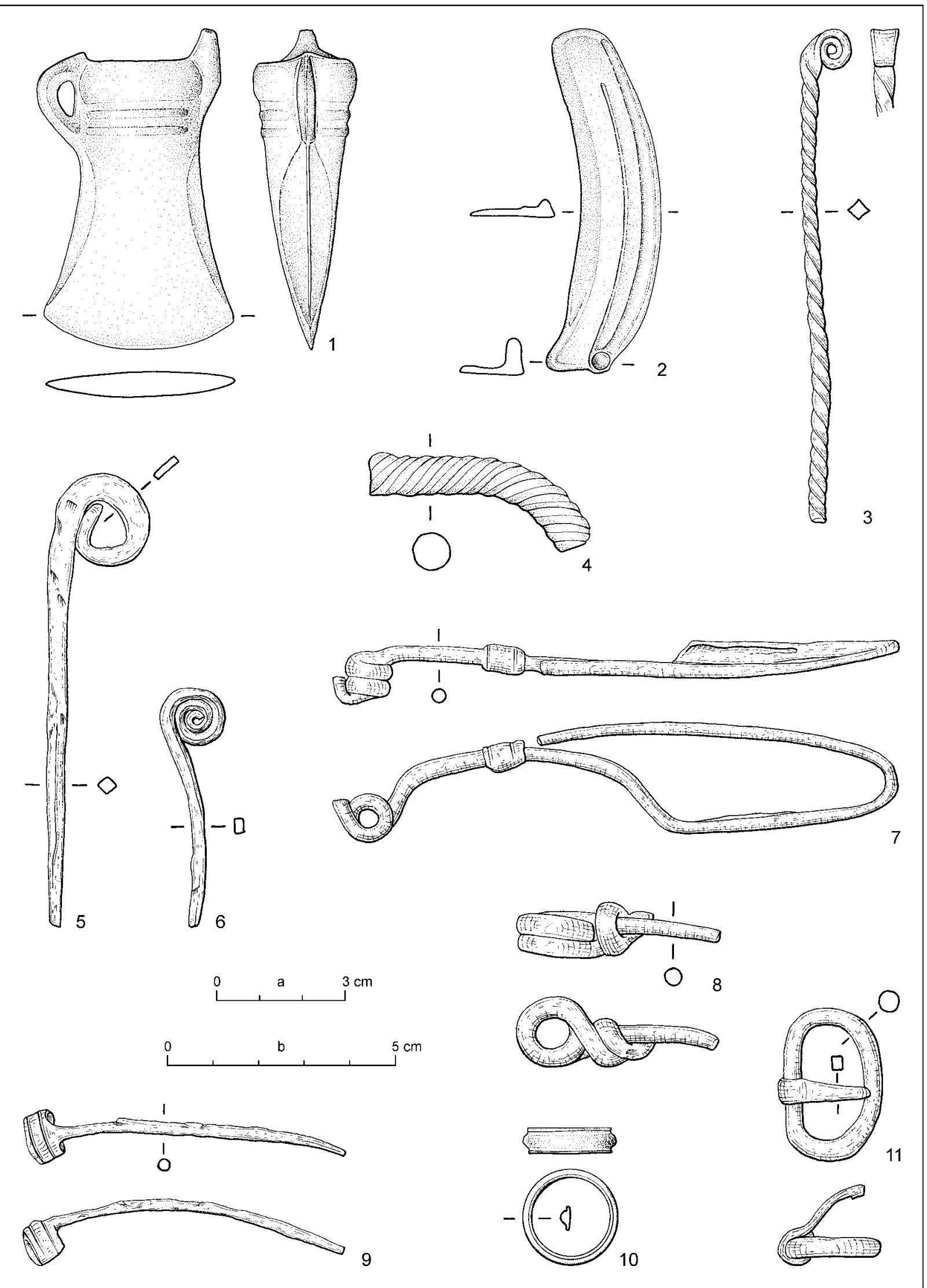

Obr. 13. Kláštor pod Znievom-Zniev. Zber na stráňach kopca. 1-3, 6, 7, 9, 10 - železo; 4, 5, 8 - bronz. Mierka: a - 1, 2; b-3-11. 
Počas neskorších povrchových prieskumov mimo areál pamiatky sa potvrdilo osídlenie blízkeho okolia na terasovite upravených nižších častiach severných i južných svahov kopca. Podla získaných nálezov bolo toto dominantné a historicky významné miesto i svahy pod ním využívané už v dobe bronzovej. $\mathrm{Z}$ tejto doby sa $\mathrm{v}$ literatúre spomína aj hromadný nález, údajne z okolia Kláštora pod Znievom (Furman 2015, s literatúrou). Malý kosák (obr. 13: 2) patrí k najstarším artefaktom, azda už z konca strednej či zo začiatku mladšej doby bronzovej (za posúdenie nálezu dakujem L. Veliačikovi). Kontinuitu využívania tohto miesta $\mathrm{v}$ neskorej dobe bronzovej a $\mathrm{v}$ dobe halštatskej potvrdzujú dalšie nálezy (obr. 13: 3-6).

Zdá sa, že terasy pri úpätí vrchu Zniev boli najintenzívnejšie využívané $\mathrm{v}$ mladšej dobe železnej. Zlomky železných spôn spojenej konštrukcie kladú tento horizont osídlenia niekde na koniec strednej alebo do neskorej doby laténskej. Mimoriadnym nálezom je drobná bronzová plastika, nájdená na jednej z terás pri južnom úpätí hradného vrchu. Zobrazuje vtáčika s rozprestretými krídlami, stojaceho na podložke, ktorá slúžila na pripevnenie plastiky k podložke dvomi nitmi (obr. 14). Patrí do dnes už početnej skupiny drobných zvieracích plastík, známych $\mathrm{v}$ rôznych variantoch ich stvárnenia a upevnenia najmä $\mathrm{z}$ vel'kých výrobno-obchodných stredísk s tažiskom osídlenia koncom stredolaténskeho obdobia (Němčice nad Hanou, Nowa Cerekwija: M. Čižmář 2012, obr. 11: 5; Rudnicki 2014, 429). Nechýbajú ani na hradiskách na Považí a Ponitrí, kde bol motív vtáka použitý v podobe príveskov či aplikovaných plastík na dnes už neznámych (kultových) objektoch, ale aj na náramkoch (JežǐškoválPieta 2019, 81; Pieta 2010, 330, obr. 137: 1, 2; F 32: 1-3). K tomuto horizontu patrí aj železná sekera (obr. 15: 4) a hrot typickej úzkej radlice s tulajovite upraveným hrotom (obr. 15: 3). Tento typ bol rozšírený najmä na území púchovskej kultúry, s presahmi do okolitých oblastí (I. Čižmár 2012, 139, 140, obr. 4). Počty týchto radlíc sa v ostatnej dobe ešte rozšírili (Blatnica, Mikušovce, Soblahov, Uhrovské Podhradie).

Neisté, ale vel'mi pravdepodobné je (refugiálne) využitie vrchu v neskorej dobe rímskej, ale najmä na začiatku stredoveku, ktoré naznačujú niektoré nálezy, medzi iným aj bronzová hrkálka (obr. 15: 5). Tvary nájdených nožov a hrotov šípov (obr. 16: 1,3-5, 7-9) tiež svedčia o využívaní tejto polohy v uvedených obdobiach. Staršie sídliskové vrstvy a stavby na vrchu Zniev v minulosti značne narušila činnost', spojená s výstavbou a prevádzkou hradu, nazývaného tiež Turiec. Preto jednoznačný obraz staršej histórie tohto exponovaného miesta môže priniest̉ len systematický prieskum, zameraný na identifikáciu predpokladaného staršieho opevnenia na tomto mieste.

Osídleniu Turca na počiatku stredoveku bola opakovane venovaná pozornost', inšpirovaná najmä atraktívnymi hrobovými nálezmi, objavenými ešte v 19. storočí. Doterajší výskum sa opieral aj o historické pramene a všímal si tiež jazykovedné analýzy (súhrnne Beňko 1996; Šalkovský 2011). Napriek tomu zostávajú naše poznatky $\mathrm{v}$ tomto smere značne neúplné. Velkostou i nálezovým inventárom pomerne skromné agrárne sídliská z tejto doby poznáme predovšetkým z nížinných polôh Turčianskej kotliny (Rakovo, Sučany, Ivančiná: Odler 2011; 2014; Kláštor pod Znievom: Horňák/Krištofová/Kvietok 2013). Citelnú medzeru predstavuje spolahlivé spoznávanie výšinných sídel, ktoré boli vybudované či využivané vo včasnohistorickom období. Ani intenzívne prieskumy v ostatných rokoch nepriniesli v tomto smere významnejšie nové poznatky. Poskytli však niektoré zaujímavé zistenia. K nim patrí skutočnost', že dnes už dobre zdokumentovaný dlhý úsek západných predhorí Vel'kej Fatry vykazuje početné a nálezovo mimoriadne bohaté výšinné lokality lužickej a púchovskej kultúry (Horňák 2015; Pieta 2014), ale prekvapujúco len málo nálezov z nasledujúcich storočí, t. j. z mladšej doby rímskej a zo stahahovania národov. To platí aj o nálezoch z počiatku stredoveku, a to napriek tomu, že sa tu na základe staršej literatúry predpokladalo viacero opevnení z tejto doby (Šalkovský 2011, 34). Je to tiež d'alší, i ked' nepriamy argument pre spochybnenie lokalizácie blatnického nálezu s jeho potenciálnym zázemím (Odler 2011, 25; Robak 2017). 


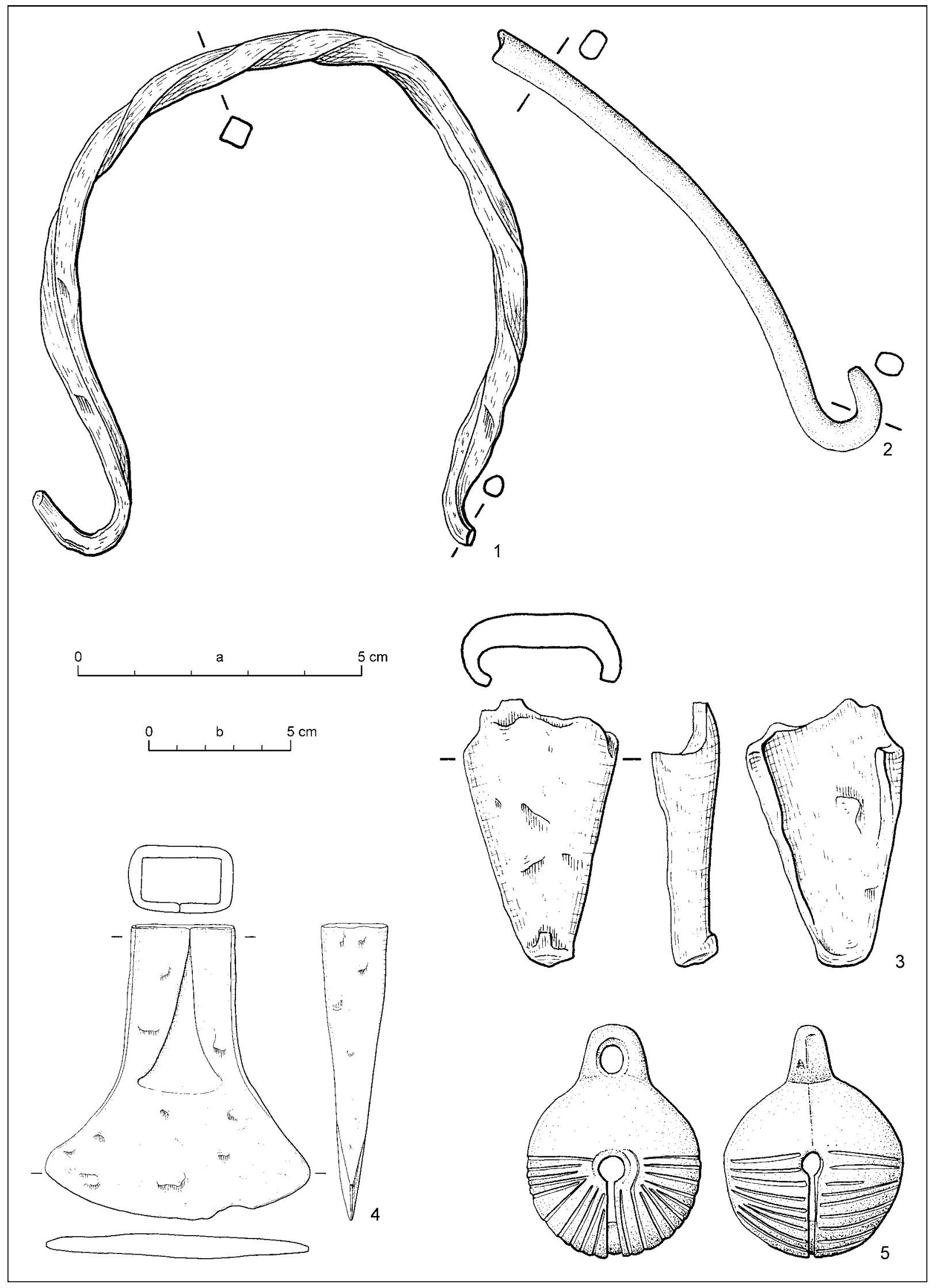

Obr. 15. Kláštor pod Znievom-Zniev. Zber na južných svahoch kopca. Železo. Mierka: a - 1-3, 5; b-4. 


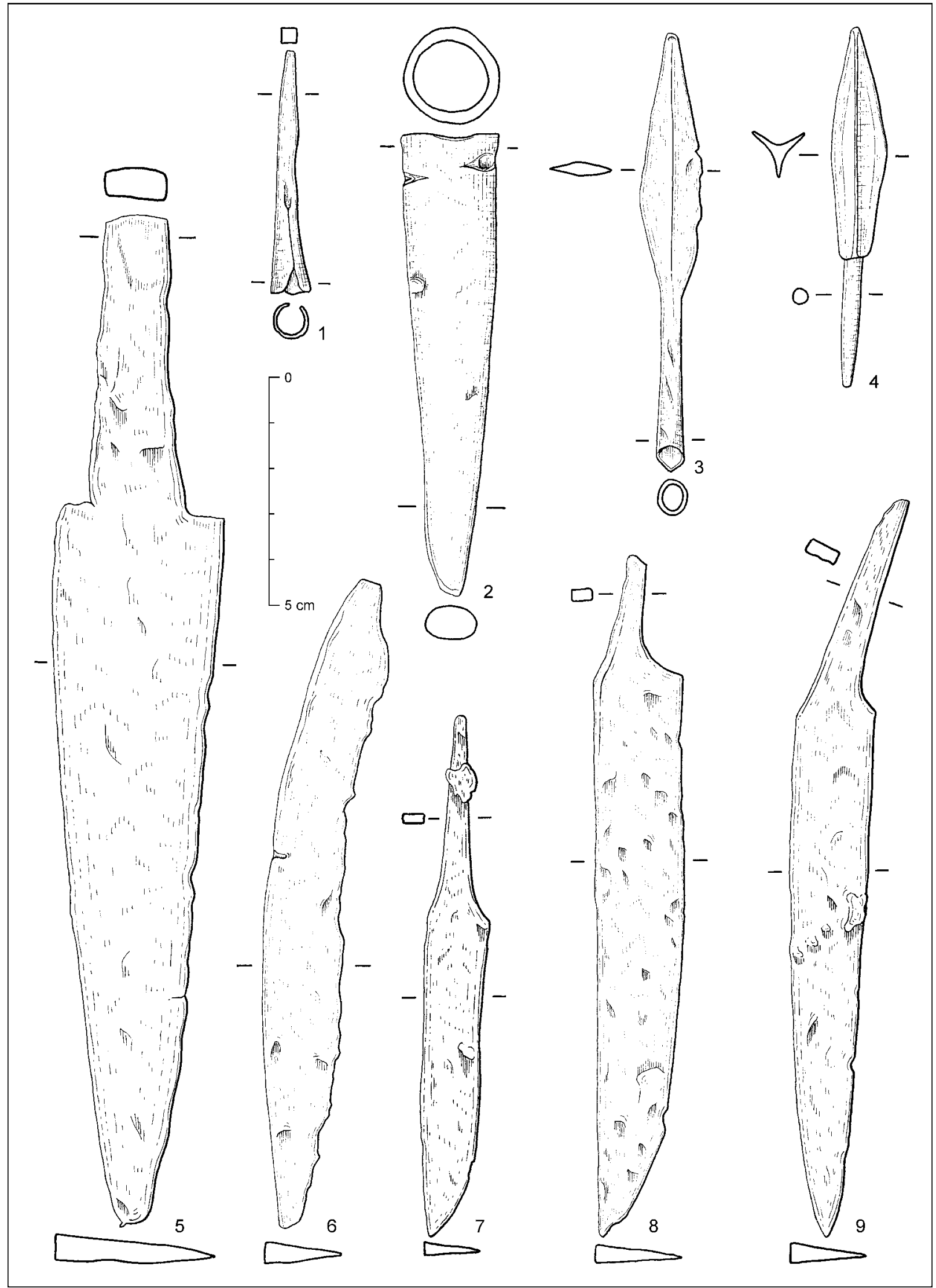

Obr. 16. Kláštor pod Znievom-Zniev. Zber na južných svahoch kopca. Železo. 
Aj výšinné opevnené polohy Dolného Turca, sústredené v severnej časti regiónu sú do včasného stredoveku datované prevažne len sporadickými a často neoverenými staršími nálezmi zlomkovej keramiky s neistým datovaním (Ruttkay 1992, 54, 55; Šalkovský 2011, 93, 94). Preto ich spolahlivé zaradenie do tohto obdobia a ich význam bude musiet preverit d’alší výskum.

V Hornom Turci bolo doteraz známe len hradisko Jasenovo-Vyšehrad, strategicky položené ned’aleko priesmyku s cestou vedúcou do Ponitria. Viacročný výskum, realizovaný v 70. rokoch 20. storočia tu potvrdil osídlenie $\mathrm{z}$ neskorej doby bronzovej, $\mathrm{z}$ mladšej doby laténskej a včasného i neskorého stredoveku (Remiašová 1975; 1980). Využitie polohy vo velkomoravskom období dokazujú najmä nálezy ostrôh. Kontinuitu využívania tejto dôležitej polohy dokumentuje ostroha s dlhými ramenami a bodcom, členeným dvomi plastickými prstencami, nelegálne získaná na hradisku niekedy pred rokom 2000. Ramená sú zdobené dvojitými lomenicami, kombinovanými s kruhovými puncami (obr. 17). Patrí do skupiny ostrôh s dlhým bodcom, známych z výbavy bojovníckych hrobov z 10. storočia (Kind 2002, 292; Profantová 2013, 73, 74).

Nové materiály z Ondrašovej, ned’aleko Abramovej-Polerieky a zrejme tiež zo Znieva, napriek obmedzenému výskumu a nevel'kému počtu výraznejších nálezov, rozšírili doteraz nízky počet výšinných polôh $\mathrm{v}$ regióne Turca, bezpečne patriacich do včasného stredoveku. Napriek tomu zostáva obraz osídlenia tejto časti Slovenska v 9.-10. storočí nad’alej nejasný a hustota dobového osídlenia pomerne malá. V tomto ohlade sa, podla súčasného stavu poznania, pohlad na kolonizáciu územia na počiatku stredoveku velmi neodlišuje od situácie v susedných regiónoch Oravy a Liptova, kde sa doposial' zistilo len niekol'ko osád a výšinných polôh nevel'kých rozmerov, využívajúcich staršie valové opevnenia. Jedine z týchto dominantných miest tiež pochádzajú hromadné nálezy železných predmetov (Vyšný Kubín, Prosiek: Pieta 2016). Aj z Turca je doteraz známy len jeden takýto depot (Sklabiňa). Na druhej strane, malé vzdialenosti medzi novo objavenými výšinnými lokalitami (jeden, resp. dva kilometre vzdušnou čiarou) v krátkom úseku východných výbežkov Malej Fatry naznačujú, že v tejto časti kotliny existovala väčšia hustota osídlenia, než to naše doterajšie poznatky ukazujú.

Stále nezodpovedaná je aj otázka počiatkov slovanského osídlenia sledovaného regiónu. Napriek intenzívnym terénnym prieskumom sa na hradiskách v Turci dosial’ nepodarilo objavit žiadne nálezy z predvel'komoravského obdobia, ako napríklad avarské kovania, ktoré sa pomerne bežne vyskytujú v zberových materiáloch na výšinných lokalitách stredného Považia či horného Ponitria. Po oprávnenom spochybnení blatnického nálezu zostáva jediným spolahlivým dokladom staršieho horizontu zlomok bronzového kovania neskoroavarského typu z hrobu v Malom Čepčíne, získaný pri kontrolnom výskume V. Budinského-Kričku (Budaváry 1936). Aktuálnou úlohou dalších prác je preverit $\mathrm{v}$ teréne ešte viditelné mohyly a pokúsit sa o výskum niektorej z nich, skôr než ich násypy na polnohospodársky obrábaných pôdach úplne zaniknú. Argumentáciu pre vplyv či kolonizáciu osídlenia Turčianskej kotliny z Hornej Nitry posilnili nové objavy významnej aglomerácie hradísk z 9.-10. storočia v Nitrických vrchoch, v katastroch Dolných Vesteníc a Uhrovského Podhradia, kde je tiež prítomný starší sídliskový horizont zo 7.-8. storočia (Pieta 2019). Okrem jednotlivých kovových predmetov z oboch hradísk v Dolných Vesteniciach to potvrdzuje aj súbor keramických nádob, nájdený a zdokumentovaný v jaskyni v okolí 
Uhrovského Podhradia v roku 2019. Táto koncentrácia výšinných lokalít dopíňa obraz hustého osídlenia Hornej Nitry s potenciálom expanzie smerom na sever (Šalkovský 2013).

Tento krátky príspevok nemal ambíciu podrobne analyzovat počiatky slovanskej kolonizácie a podobu včasnostredovekého osídlenia Turca. Chcel len novými preverenými nálezmi prispiet k spresneniu doteraz len málo konkrétneho obrazu osídlenia tohto regiónu na počiatku stredoveku.

\section{LITERATÚRA}

Balaša 1964

Bartošková 1986

Beňko 1996

Beranová 1991

Borzová 2016

Budaváry 1936

Bujna 2003

Csuthy 2019

Czarnecka 2013

Čaplovič 1987

Furman 2015

Geisler/Kohoutek 2014

Hanuliak/Kuzma 2015

Henning 1987

Holeščák 2019

Horňák 2015

Husár 2014

I. Čižmář 2012

Jacobi 1974

Jakubčinová 2018

Ježišková/Pieta 2019

Kind 2002
G. Balaša: Hrad Zniev (Turčiansky) vo svetle najnovších archeologických výskumov. Vlastivedný zborník Považia 6, 1964, 262-271.

A. Bartošková: Slovanské depoty železných předmětů v Československu. Studie Archeologického ústavu Československé akademie věd 13. Brno 1986.

J. Beňko: Starý Turiec. Martin 1996.

M. Beranová: Slavic Harvest and Harvesting Implements until the Beginning of the $15^{\text {th }}$ Century. Ethnologia Slavica 23, 1991, 7-36.

Z. Borzová: Polnohospodárske náradie včasného stredoveku na Slovensku. Nitra 2016.

V. Budaváry: Zpráva o výskume „Homôlky“ v Malom Čepčíne (okr. Turčiansky Sv. Martin) r. 1936. Sborník muzeálnej slovenskej spoločnosti 30, 1936, 94-100.

J. Bujna: Spony z keltských hrobov bez výzbroje z územia Slovenska (typologicko-chronologické triedenie LTB a LTC spôn). Slovenská archeológia 51, 2003, 39-108.

A. Csuthy: Horse Harness Rattles from the Avar Period. In: L. Poláček/P. Kouřil (Hrsg.): Bewaffnung und Reiterausrüstung der 8. Bis 10. Jahrhunderts in Mittelauropa. Waffenform und Waffenbeigaben bei den mährischen Slawen und in den Nachbarländern. Internationale Tagungen in Mikulčice IX. Brno 2019, 351-358.

K. Czarnecka: Padlocks in the Przeworsk and the Cherniakhov Cultures in the Late Roman Period as the Evidence of Mutual Contacts. In: I. Khrapunov/F.-A. Stylegar (ed.): Inter Ambo Maria. Northern Barbarians from Scandinavia towards the Black Sea. Kristiansand - Simferopol 2013, 69-82.

P. Čaplovič: Orava v praveku, včasnej dobe dejinnej a na začiatku stredoveku. Martin 1987.

M. Furman: Archeologické náleziská. In: K. Ďurian a i.: Pamiatková zóna obce Kláštor pod Znievom. Zásady ochrany pamiatkového územia. Martin 1915, 68-77. Dostupné na internete: www.pamiatky.sk/Content/PZ_zasady/Klastor pod Znievom.

M. Geisler/J. Kohoutek: Vysoké pole - Kláštov. Inventář hromadných nálezů železných předmětů a shrnutí terénních výzkumných sezon 2005-2007. Pravěk Supplementum 28. Brno 2014.

M. Hanuliak/I. Kuzma: Mužla-Čenkov II. Osídlenie z 9.-13. storočia. Archaeologica Slovaca Monographiae. Studia XXV. Nitra 2015.

J. Henning: Südosteuropa zwischen Antike und Mittelalter. Archäologische Beiträge zur Landwirtschaft des 1. Jahrtausends $u$. Z. Schriften zur Ur- und Frühgeschichte 42. Berlin 1987.

M. Holeščák: Medieval archery equipment from the territory of Slovakia. Archaeologica Slovaca Monographiae. Studia XXXI. Nitra 2019.

M. Horňák: Hradiská lužickej a púchovskej kultúry v Turci. In: Hradiská - svedkovia dávnych čias. Zborník odborných príspevkov o hradiskách a ich obyvateloch. Horná Maríková 2015, 33-43.

M. Husár: Žrd’ovo-bodné zbrane včasného stredoveku v Karpatskej kotline 1. Typológia a jej vyhodnotenie. Nitra 2014.

I. Čižmář: Železný depot z Př́lep. In: G. Březinová/V. Varsik (ed.): Archeológia na prahu histórie. K životnému jubileu Karola Pietu. Archaeologica Slovaca Monographiae. Communicationes XIV. Nitra 2012, 137-143.

G. Jacobi: Werkzeug und Gerät aus dem Oppidum von Manching. Ausgrabungen in Manching 5. Wiesbaden 1974.

M. Jakubčinová: Výstroj jazdca a koňa v 9. stor. z územia dnešného Slovenska s prihliadnutím na nálezy v Bojnej. Dizertačná práca. Archeologický ústav SAV. Nitra 2018. Nepublikované.

L. Ježišková/K. Pieta: Laténske hradisko v Stupnom. Študijné zvesti AÚ SAV 65, 2019, 71-88.

Th. Kind: Archeologische Funde von Teilen der Reitausrüstung aus Europa und ihr Beitrag zur Kultur- und Sozialgeschichte der Ottonenzeit. In: J. Henning 
Klanica 2006

Klíma 1980

M. Čižmář 2012

Odler 2011

Odler 2014

Pieta 1982

Pieta 2007

Pieta 2010

Pieta 2014

Pieta 2016

Pieta 2019

Pieta/Švihurová 2019

Pomberger/Stadler 2019

Profantová 2013

Remiašová 1975

Remiašová 1980

Robak 2013

Robak 2017

Rudnicki 2014

Ruttkay 1992

Schuster 2010

Šalkovský 2011

Šalkovský 2013

Vanglová 2010
(Hrsg.): Europa im 10. Jahrhundert. Archäologie einer Aufbruchszeit. Mainz 2002, 283-299.

Z. Klanica: Nechvalín, Prušánky. Čtyři slovanská pohřebiště 1. Příspěvek ke chronologii časněstředověké hmotné kultury ve střední Evropě. Spisy AÚ AV ČR Brno 28. Brno 2006.

B. Klíma: Zámečnické práce staromoravských kovárư v Mikulčicích. Studie Archeologického ústavu Československé akademie věd v Brně 8. Brno 1980.

M. Čižmář: Nálezy drobné lidské a zvířecí plastiky z Moravy. In: G. Březinová/ V. Varsik (ed.): Archeológia na prahu histórie. Kživotnému jubileu Karola Pietu. Archaeologica Slovaca Monographiae. Communicationes XIV. Nitra 2012, 145-173.

M. Odler: Praveké a stredoveké nálezy z Rakova, miestnej časti Lehôtka. Zborník Slovenského národného múzea v Martine. Kmetianum 12, 2011, 19-33.

M. Odler: Včasnostredoveké sídlisko Ivančiná-Kratiny (okres Turčianske Teplice). Zborník Slovenského národného múzea v Martine. Kmetianum 13, 2014, 18 -58.

K. Pieta: Die Púchov-Kultur. Nitra 1982.

K. Pieta: Hradiská Bojná II a Bojná III. Významné sídlo z doby stahovania národov a opevnenia z 9. storočia. Burgwälle Bojná II a III. Herrensitz der Völkerwanderungszeit und Befestigungen aus dem 9. Jahrhundert. In: K. Pieta/A. Ruttkay/ M. Ruttkay (ed.): Bojná. Hospodárske a politické centrum Nitrianskeho kniežatstva. Wirtschaftliches und politisches Zentrum Nitraer Fürstentums. Nitra 2007, 173-190.

K. Pieta: Die keltische Besiedlung der Slowakei. Jüngere Latènezeit. Archaeologica Slovaca Monographiae. Studia XII. Nitra 2010.

K. Pieta: Hradiská vo Folkušovej - Necpaloch a Blatnici. Juhovýchodné prvky v púchovskej kultúre. Slovenská archeológia 62, 2014, 125-165.

K. Pieta: Hromadné nálezy z Prosieka a Dolného Kubína. Poznámky k včasnostredovekému osídleniu Liptova a Oravy. Slovenská archeológia 64, 2016, 261-279.

K. Pieta: Hradiská pri Dolných Vesteniciach. Burgwallanlagen bei Dolné Vestenice. AVANS 2014, 2019, 120-123.

K. Pieta/M. Švihurová: Influence of the Przeworsk culture in the Púchov culture milieu. Acta Archaeologica Carpathica 54, 2019, 107-128.

B. M. Pomberger/P. Stadler: Der Klang der Schellen. Schellenfunde aus dem awarischen Gräberfeld von Vösendorf-Laxenburgerstraße, Österreich. Študijné zvesti AÚ SAV 63, 2019, 125-146.

N. Profantová: Frühmittelalterliche Gräber mit Sporen aus Böhmen. In: F. Biermann/Th. Kersting/A. Klammt (Hrsg.): Soziale Gruppen und Gesellschaftsstrukturen im westslawischen Raum. Beiträge zur Ur- und Frühgeschichte Mitteleuropas 70. Langenweissbach 2013, 57-76.

M. Remiašová: Archeologický výskum na hradisku Vyšehrad. AVANS 1974, 1975, 91-92.

M. Remiašová: Hradisko Vyšehrad. Horná Nitra 9, 1980, 13-30.

Z. Robak: Studia nad okuciami rzemieni w typie karolińskim VIII-X wiek. II. Archeologica Slovaca. Studia 18. Nitra 2013.

Z. Robak: The Origins and the Collapse of the Blatnica-Mikulčice Paradigm. Slovenská archeológia 65, 2017, 99-162.

M. Rudnicki: Nowa Cerekwia - The Middle La Tène centre of power north of the Carpathians. In: J. Čižmářová/N. Venclová/G. Březinová (ed.): Moravské kř̌ižovatky. Střední Podunaji mezi pravěkem a historií. Brno 2014, 421-436.

M. Ruttkay: Okres Martin. In: D. Bialeková (ed.): Pramene k dejinám osídlenia Slovenska z konca 5. ažz 13. storočia. 2. zv. Stredoslovenský kraj. Nitra 1992, 53-69.

J. Schuster: Der Kasten (Schüssel, Riegel, Abdeckbleche, Holzreste). In: M. Becker (ed.): Das Fürstengrab von Gommern. Veröffentlichungen des Landesamtes für Denkmalpflege und Archäologie Sachsen-Anhalt. Landesmuseum für Vorgeschichte 53. Halle Saale 2010, 121-148.

P. Šalkovský: Stredné Slovensko vo včasnom stredoveku. Archaeologica Slovaca Monographiae. Studia XIV. Nitra 2011.

P. Salkovský: Sídelný vývoj v povodí hornej Nitry v starších fázach stredoveku. Slovenská archeológia 61, 2013, 143-175.

T. Vanglová: Stredoveká keramika na severozápadnom Slovensku. Študijné zvesti AÚ SAV 48, 2010, 91-140. 


\title{
New early medieval finds in Turiec
}

\author{
Ka rol Pieta
}

Summary

The region of Turiec is an area important for learning about the beginnings and development of the early medieval settlement of the Western Carpathians. Current archaeological sources do not correspond with this importance with their extent or reliability of older finds. The contribution brings information and material from three upland settlements from the eastern foothills of the Lesser Fatra mountains, which will help us complement and explain the current state.

On the rocky top of the hill of Ondrašovské skaly $(812 \mathrm{~m}$ a. s. 1.) near the village of Ondrašová, Turčianske Teplice district (Fig. 1), rampart fortification protecting the more easily accessible western and northern sides of the hilltop was detected. From other sides, the hillfort was protected by rock walls. The highest spot in the southeastern corner was separated by another rampart of piled stones (Fig. 2; 3). A survey with metal detectors detected traces of settlement also on the western and northwestern slopes of the hill, where - besides other finds - two sickles were discovered together (Fig. 4 ; 6). Use of the site in the Middle La Tène stage LTC1 is documented by an iron fibula with one-piece construction discovered at the foot of the hill (Fig. 5: 6). There is a peculiarity in its construction - the end of the foot is attached to the bow with a rivet, which is a rare technical feature. Sickles with arcuate blades and serrated cutting edges (Fig. 6) belong to the classical forms of the early medieval harvest tools (Beranová 1991; Borzová 2016, 59; Henning 1987, 89). According to the remains of plant preserved in the surface corrosion of one of the blades, the sickles were hidden or left in a heap of grass or hay. Two Hoards of two and of seven sickles have been recently discovered near the hillfort of Dolné Vestenice II in the Upper Nitra region (Pieta 2019).

Documents of settlement were concentrated over the inner area of the hillfort. Ceramic fragments and metal artefacts were scattered all over the area, with a concentration on the internal rampart at the highest point of the hillfort. The most important finds include an iron end fitting from a belt with three fastening rivets in a row below the edge decorated with three plastic protuberances divided by a tape in shape of upturned letter Y (Fig. 5: 2). This decorative motif is widely used in Moravia and mainly in Slovakia. The highest number of such elements was discovered at the hillfort of Bojná I, whose main period falls to the end of the $9^{\text {th }}$ century (Robak 2013, 179-181, map 2). An iron rattle (Fig. 5: 5) with analogies at hillforts from the $9^{\text {th }}$ century, including Bojná, comes from the same period. These sound producing decorations were part of horse harnesses as well as children's, women's and men's clothes in the $8^{\text {th }}-9^{\text {th }}$ centuries (Csuthy 2019; Pomberger/Stadler 2019). Hook-shaped, rotary and insertion types of keys obtained in the area of the hillfort (Fig. 7: 3, 5, 6) belong to several closing systems of doors, chests or caskets used in our environment as early as the La Tène and Roman periods (Czarnecka 2013; Jacobi 1974, 153-166). We can find their almost unchanged designs in the Early Middle Ages.

Bucket fittings are represented by fragments of rings and mainly typical attachment fittings which are represented by several types among the finds from the hillfort (Fig. 8: 1, 2, 4, 7; Hanuliak/Kuzma 2015, 88, 89, with lit.; Klanica 2006, 71-73). A large winged arrowhead with specific attachment by means of a tang (Fig. 10: 3) is undoubtedly medieval. It could be an arrowhead from an arrow fired from an arrow launching gun, but it is more probably part of a trap - a defensive or hunting device.

The fortification on Ondrašovské skaly consists of two lines of ramparts using the good defensive properties of the difficultly accessible rocky terrain. One of the fortifications (the larger one?) was probably built as early as the Middle La Tène period and the second - interior - rampart was probably constructed in the 9th century, when both fortification lines might have been used or adapted for the defense. The obtained material suggests short-term use of this rather remote and difficultly accessible site. Slag and iron semi-finished products (Fig. 8: 3, 6; 9: 8) document local blacksmith's production.

Survey of the eastern foothills of the Lesser Fatra brought evidence of settlement at two other sites which are only one or two kilometres (air distance) far from the hillfort in Ondrašová. Multiple finds from the end of the Early Roman period (Fig. 12: 9) and Early Middle Ages come from the fortification on the hill west of the village of Abramová-Polerie$\mathrm{ka}$ and its vicinity. We should pay attention mainly to the winged spear (Fig. 12: 8) which belongs to arms with variable shapes and longer time span of their use during the $8^{\text {th }}$ and $9^{\text {th }} / 10^{\text {th }}$ centuries. The specimen from Polerieka, which is $466 \mathrm{~mm}$ long, belongs - according to the classification by M. Husár - to his type BA, variant d (Husár 2014, 33-36).

On the hill of Zniev with ruins of a medieval castle $(985 \mathrm{~m})$ near the village of Kláštor pod Znievom, finds from the end of the Middle and the beginning of the Late Bronze Age (Fig. 13: 2) were detected and the continuity of use of this site in the Late Bronze Age and the Hallstatt period is confirmed by other finds (Fig. 13: 3-6). Terraces at the foot of Zniev hill were most intensely settled in the Late Iron Age. Fragments of iron fibulae with attached foot put this settlement horizon somewhere to the end of the Middle or in the Late La Tène period. A miniature bronze figurine discovered on one of the terraces on the southern foot of the castle hill is an exceptional find (Fig. 14). It belongs to the group of miniature zoomorphic figurines known mostly from the large production-trade centres settled mainly in the end of the Middle La Tène period (Němčice nad Hanou, Nowa Cerekwia: M. Čižmář 2012, fig. 11: 5; Rudnicki 2014, 429). 
They are also present at the hillforts in Považie and Ponitrie regions (Ježišková/Pieta 2019, 81; Pieta 2010, 330, fig. 137: 1, 2; F 32: 1-3). According to other finds, we presume that this exposed site was used also at the end of the Roman period and the Early Middle Ages (Fig. 14: 5; 15; 16: 1, 3-5, 7-9).

Thanks to the attractive warrior burials studied in the 19th century, Turiec was regarded as an important region of the early medieval colonization of the Western Carpathians (summarized in Beňko 1996; Šalkovský 2011). Critical reassessment of older sources, mainly the collection of finds from Blatnica, as well as systematic surveys in the last years point to the small number of sites from this period in the eastern part of the Turiec - basin. Hillforts in the northern part of the region in Dolný Turiec were dated only on the basis of little significant pottery. In the south, only the important hillfort of Jasenovo, Vyšehrad, has been known. There, a spur with a long neck from the $10^{\text {th }}$ century was added to the elder finds coming from the $9^{\text {th }}$ century (Fig. 17; Kind 2002; Profantová 2013).

New materials from Ondrašová, Abramová-Polerieka and Zniev extended the previously low number of upland sites in the region of Turiec positively belonging to the Early Middle Ages. Despite this fact, the number of Slavonic sites remains low. Even the expected Pre-Great Moravian horizon is represented only sporadically (Malý Čepčín: Budaváry 1936), which is in contrast with the situation in the neighbouring region of Horná Nitra (Upper Nitra valley), where new hilltop sites from the $7^{\text {th }}-8^{\text {th }}$ centuries were discovered (Pieta 2019).

Fig. 1. Ondrašová, Ondrašovské skaly. General view from south-west. Photo K. Pieta.

Fig. 2. Ondrašová, Ondrašovské skaly. 1 - view of western part of the outer rampart from the north; 2 - inner rampart; 3 - northern part of outer rampart, view from south-east. Photo K. Pieta.

Fig. 3. Ondrašová, Ondrašovské skaly. Plan of the hillfort. Plan by M. Bartík and K. Pieta.

Fig. 4. Ondrašová, Ondrašovské skaly. Sickles uncovered on the slope of the hill. Photo K. Pieta.

Fig. 5. Ondrašová, Ondrašovské skaly. 1-5 - finds inside the ramparts; 6 - brooch found on the foot of the hill. 1, 3, 4 - bronze; $2,5,6$ - iron.

Fig. 6. Ondrašová, Ondrašovské skaly. Sickles hoarded on western slope outside of hillfort. Iron.

Fig. 7. Ondrašová, Ondrašovské skaly. Finds insides of ramparts. Iron.

Fig. 8. Ondrašová, Ondrašovské skaly. Dove buckets fittings and scrap iron from the hillfort. Iron.

Fig. 9. Ondrašová, Ondrašovské skaly. Finds from the hillfort. Iron.

Fig. 10. Ondrašová, Ondrašovské skaly. Tip of unknown purpose (trap?) and the knives from the hillfort. Iron.

Fig. 11. Ondrašová, Ondrašovské skaly. Pottery.

Fig. 12. Abramová-Polerieka. 1-8, 10 - finds inside the fortification; 9 - brooch from the slope of the hill. Iron. Scale: $\mathrm{a}-1-5,9,10 ; \mathrm{b}-6-8$.

Fig. 13. Kláštor pod Znievom-Zniev. Selected finds from the slopes of the hill. 1-3, 6, 7, 9, 10 - iron; 4, 5, 8 - bronze. Scale: $\mathrm{a}-1,2 ; \mathrm{b}-3-11$.

Fig. 14. Kláštor pod Znievom-Zniev. Small bird sculpture found on the southern slope of the hill. Bronze.

Fig. 15. Kláštor pod Znievom-Zniev. Small finds from the southern slope. Iron. Scale: $a-1-3,5 ; b-4$.

Fig. 16. Kláštor pod Znievom-Zniev. Small finds from the southern slope. Iron.

Fig. 17. Jasenovo, Vyšehrad. Spur from the hillfort. Iron.

PhDr. Karol Pieta, DrSc

Archeologický ústav SAV

Akademická 2

SK - 94921 Nitra

karol.pieta@savba.sk 